\title{
Knowledge management in industrial companies
}

\author{
ELMORTADA Asmaa \\ Research Team in Industrial Engineering, University Cadi Ayyad Morocco, Higher School of \\ Technology of Safi_ Morocco \\ MOKHLIS Chams Eddoha \\ Associate Professor, Higher Istitut of Commerce and Business Administration Group(ISCAE) \\ MOKHLIS Ahmed et ELFEZAZI Said \\ Research Team in Industrial Engineering, University Cadi Ayyad Morocco, Higher School of \\ Technology of Safi_ Morocco \\ asmaa.elmortada@gmail.com, selfezazi@gmail.com, y mokhlis@yahoo.fr, chams.hebiz@yahoo.fr
}

\begin{abstract}
$\underline{\text { Abstract }}$
The industrial enterprise as a development organization of the country is as also concerned by the formation of its own elite. Indeed, in an economic environment increasingly complex and competitive, companies, especially those of industrial activity are now aware, more than ever, of the importance of knowledge management of their human resources as a primary factor for strengthening the innovative spirit of its employees, and therefore the performance of the different chains of the business.

The concern of this article is, first, to describe the reasons for the emergence of the concept of knowledge management within firms. On the other hand, we will try to highlight the interests and objectives of this type of management, but more importantly, to highlight the difficulties and limitations of the application of its procedures.
\end{abstract}

\section{Keywords:}

Human resource management, knowledge management, strategic management, industrial performance, training...

\section{Résumé}

L'entreprise en tant qu'organisme de développement du pays est aussi concernée par la formation de sa propre élite. En effet, dans un environnement économique de plus en plus complexe et compétitif, les entreprises, notamment celles d'activité industrielle, sont aujourd'hui conscientes, plus que jamais, de l'importance de la gestion des connaissances de leurs ressources humaines en tant que facteur primordial pour le renforcement de l'esprit innovant de ses employés, et donc de la performance des différentes chaines de l'entreprise.

Le souci du présent article est, en premier lieu, de décrire les raisons de l'émergence du concept de gestion du savoir au sein des entreprises. De l'autre part, nous allons essayer de mettre en relief l'intérêt et les objectifs de ce type de management, mais surtout, de souligner les difficultés et les limites de l'application de ses démarches.

\section{Mots clés:}

Gestion des ressources humaines, gestion du savoir, management stratégique, performance industrielle, la formation... 


\section{Introduction}

The interest in the problematics of knowledge is a recent issue even if it was dealt in 1968 by Galbraith [1968], which depicted a company focused on intellectual activity. Similarly, Drucker [7,8,9] Bell [4] and Toffler [17] discussed the advent of "knowledge workers" in a "knowledge society" where the main source of wealth creation come from intellectual activities. Stuart [16], for its part, announced the transition from an industrial economy to a "knowledge-based" economy. Knowledge is now recognized as a driver of productivity and economic growth. "In a more organizational perspective, knowledge issues are studied through themes such as memory, learning and organizational cognition, learning organizations, skills or evaluation and management of intangible elements of performance. A very large but sparsely articulated literature has thus formed around this issue, even larger than can be attached to related concerns, including on new methods of organization, change management and the innovation, etc ... [3]

\section{Definition}

Knowledge management describes a multidisciplinary approach in the use and management of the acquired knowledge within an organization based on healthy practices in information management, focused on organizational learning, recognizing the contribution and the value of employees and implementation through technology. It is primarily concerned with the nature of knowledge within the organization and the ways in which this knowledge can improve the performance of the organization. [2]

However, knowledge is distinguished from information. According Skyrme [15], unlike information, knowledge is dependent on human cognition. Although it is potentially reducible and transmissible as information, it can only be exploited if it is reappropriated through a human cognitive process. " Knowing "is a fact little different from an" information "but" know "a technique " or know "that something can affect the conditions of a market, is something that, despite efforts of engineers to codify knowledge, has an important human dimension. ? It 's a combination of meaning from context, personal memory and cognitive processes "[15] [3].

\section{Emergence of knowledge ${ }^{1}$ [3]}

The knowledge of one organization covers all the knowledge and know-how that are implemented there. There is therefore a need to consider the knowledge in action. It is a dynamic and evolving subject, which is not without major conceptual problems. However, as pointed P. Maret, "knowledge and know-how are the two inseparable aspects of knowledge ... as long as they are not controlled, they are a fragile capital because they are not shareable or persistent. They are expendable in the absence of the holder. »

The increasing number of products, variations and adaptations both technical and commercial cause « every time a more or less important and more or less recognizable adaptation of production protocols, of materials used or logistics »[11]. Therefore, it is not the environmental changes and adaptations they require that cause problems but the pace of these changes. As stated Koenig [12], "the confrontation to more dynamic and more complex situations than in the past explains that the focus is shifted to part of the management of repetition (learning curves) that could be called "learning by walking."

Thus, knowledge management as a discipline has appeared in response to a wide range of problems resulting from "memory loss" of choice, expertise or technical practices. The findings were simple: that money, energy and time devoted to research whose results had been forgotten! How to retrieve a knack once mastered! That it was useless to analyze a

\footnotetext{
${ }^{1}$ This paragraph is based in a large part on the document [3] cited in the bibliography
} 
technical solution that the design was not traceable! Could the company's practices be mature, improved, built from past experiences, failures and successes? Could they provide to human organizations a memory they would use to progress?

\section{Problematics of knowledge in the company [3]}

Depending on the objectives, the problems of knowledge experienced can be distinguished in three stages of action: knowledge creation; the capitalization of knowledge and knowledge transfer.

On the other hand, these issues may also be distinguished according to the nature of the support of this knowledge, which opposes the knowledge held in human minds and knowledge transposed on formal supports.

\section{IV.1 Knowledge creation:}

Conventional operating modes do not promote knowledge creation. They are more in a knowledge economy (in the sense of limited use) that is perfect for the limitation of human cognitive abilities as described by Simon [14]. The most elementary way for the company to build knowledge is then to foster the creation by men through the activity. Knowledge is formed naturally in the activity.

\section{IV.1.a Create knowledge in the human mind}

Such objective of creating knowledge through the activity goes against the conventional logic including separation design and construction advocated by Taylorism. This knowledge creation requires a number of preconditions that have been highlighted by the writings on the "learning organization" including transformation of organizational logics. Thus, these conditions are human, and therefore dependent on changes taking place in the minds of men, mainly:

- Cultural change: in other words, communication, exchange innovation, learning, experimentation should be encouraged as well as the acquisition and formalization of knowledge. The psychological barriers such as the "not invented here" syndrome must be overcome.

- The change in terms of power: it is not possible to initiate change, creators of new knowledge, if it has no power to change things and make the necessary adjustments. In this context, responsibility of every employee is increased. Because the first who encounters a problem becomes responsible for its resolution whatever their hierarchical level. Therefore, equality and respect become key values. Employees, whatever their level, can make contact with customers. Hence, everyone is encouraged to find and try new ideas and learn continuously. (The results of such a policy are clear: the level of quality and productivity were exceptional (1100 T / employee / year against $350 \mathrm{~T} /$ employee / year on average in the industry) [5]).

\section{IV.1.b Créer des connaissances sur des supports formels}

Initiating an institutional framework, encouraging the creation of knowledge, and setting goals in this sense are a necessary precondition for men to mobilize and exploit the knowledge that they can carry and grow. However, the application of these principles does not necessarily lead to create a useful knowledge to the company. Hence the use of formal tools, methods, and other modes of representation becomes an urgent need to materialize and structure the activity of knowledge creation.

Among the formal tools, it is possible to distinguish between:

- Tools to bring out a problem, such as indicators, collections of explicit goals (quality, charter, business plan), information systems, tools apprehension, representation, analysis ) 
- Creativity tools (brainstorming, photo-language, etc.) used to "get out of the mind", transcribe and collectively enrich original knowledge. There are also, tools that structure knowledge, and stabilize it in an explicit form and share them collectively as identification tools, categorization, and organization of different proposals (metaplan, Regnier abacus, etc.).

- Exchange and sharing tools used to make knowledge creation process beyond the level of the group they are usually implemented in, in order to achieve the scale of the entire company. Messaging, groupware and electronic forums are such means.

\section{IV.2 Capitalization of knowledge:}

As part of the capitalization of knowledge, the preservation of knowledge constituting the performance of the company, from which the company hopes to continue to benefit in the future, is the most importante. In this sense, companies choose carefully, to preserve knowledge, they are those specific to the firm or relating to an activity or an object whose usefulness may occur in the future (knowledge of a leaving person, knowledge of the context and the way in which a record has been set, errors made in the knowledge of past projects, etc.).

\section{IV.2.a Capitalize knowledge in the human mind}

In this context, it is to identify, build, evolve and enhance the value of the skills of individuals. This is part of human resource management and gradually integrates its tools and methods (human resources management software, for example, now include such skills management modules).

\section{IV.2.b Capitalize knowledge on formal holders}

The principle is to formalize knowledge used in the activity. It is to make explicit, manipulated and accessed, usually in documentary form, the components of this activity: products, processes, methods, schemes, etc. The abundance of aspects that may be the object of representation is the primary problems faced during an capitalization approach. Then, formalization has a cost, but not everything is formalized at an acceptable cost. Companies are then faced with choices: what knowledge should they primarily capitalize? Should we try to formalize the maximum knowledge to ensure that the relevant ones were captured or formalize the knowledge that has been validated and evaluated as useful? ..

\section{IV.3 The transfer of knowledge}

Transfer knowledge is the most advanced management mode. This is not only about creating the initial conditions, that promote creation and exchange of local knowledge, nor of formalizing this knowledge so as to keep them in some activity, but it is about allowing their dissemination and application to different contexts.

\section{IV.3.a The problematic of knowledge transfer}

Conceptually, the transfer of knowledge is similar to the creation of knowledge, including through the exchange and dissemination appearance. However, the creation remains a local process because of its scale, and even accommodates non structured exchanges, opportunistic informations, a random development, etc. The transfer is, however, characterized by the spatial,temporal or contextual distance. The scale is no longer local but becomes that of the company. Informal and random process that characterize the knowledge creation can no longer take place.

Similarly, knowledge that can be transferred are different. While knowledge involved during the creation process present a wide variety, capitalized knowledge appear as more formalized 
and restricted in their diversity (skills, for example, are identified in a limited referential). Transferable skills receives a further reduction due to the loss of contextual elements.

The cost of the transfer is also visible in the sense of corresponding actions and their related costs are identified. However, this transfer allows a potential gain of knowledge management such as reducing errors, reducing redundancy, promoting problem resolution, improving decision making, research costs and reduced development, increasing workers' autonomy, improving customer relationships, and improving products and services [16].

\section{IV.3.b Modes of knowledge transfer}

Among the modes of knowledge transfer, there is training in its different evolutionary forms, namely: classical classroom training, apprenticeship training in the workplace (monitoring), the Action training in the form of a group work accompanied by a consultant implementing a problem-solving, in addition to library instruction and self-study, which is to be formed individually from formal holders.

Analysis grids or specific referential of some activities could also be implemented empirically by some companies to understand the nature of knowledge. Such analytical decomposition can be used to evaluate the return of experience on some IT projects.

V. Conclusion

Knowledge creation is intended to improve the learning process. Capitalization to preserve achievements to not need to re-implement a learning process that has already been made. The transfer ambition is to manage the early stages of the learning process, that is to build it from references, indicators, methods and other elements having a certain conceptual proximity aspects of the process with the object concerned.

When creation was rooted in very rich contextual elements (especially informal ones), capitalization impoverishes these contextual elements while trying to preserve them because it had also to save knowledge and context. The transfer proceeds to further reduction, contextual elements are made by the recipient context. In this context, it is possible to say that the rich content, assessed in terms of capacity support as defined by Daft and Lengel [5] decreases from creation to knowledge transfer, as shown in the source table below: Daft, Lengel, [5]

\begin{tabular}{|c|c|}
\hline Media & Richness of transferred information \\
\hline Discussion face to face & Very High \\
\hline Video conferencing, phone conversation & High \\
\hline $\begin{array}{c}\text { Letter, memo (addressed } \\
\text { Individually) }\end{array}$ & Average \\
\hline $\begin{array}{c}\text { Formal written document } \\
\text { (newsletter or unaddressed report) }\end{array}$ & Low \\
\hline $\begin{array}{c}\text { Digital formal document } \\
\text { (budget report, computer status) }\end{array}$ & Very Low \\
\hline
\end{tabular}

Thus the problem of knowledge management appears multidimensional like the concept of knowledge. Faced with this situation, the solution seems to be: more organization of the art.

\section{Bibliography}

[1] BARTHELME-TRAPP Françoise, "Analyse comparée de méthodes de Gestion des connaissances pour une approche managériale", sur http://www.strategie-aims.com/events/conferences/13xeme-conference-de-l-aims/communications/2359-analyse-comparee-de-methodes-de-gestion -des-connaissances-pour-une-approche-manageriale, consulté le 27/10/2014 à 12:59 
[2]" La gestion des connaissances", sur http://www.memoireonline.com/07/08/1199/m_lagestiondes-connaissances8.html, consulté le 29/10/2014 à 19:56

[3] S. Duizabo et N. Guillaume, "Les problématiques de gestion des connaissances dans les entreprises", Cahier n²52, Février 1997, sur http://basepub.dauphine.fr/bitstream/handle/12345 6789/4637/CR252.pdf? sequence=1, consulté le 27/10/2014

[4] Bell D., 1973, The coming of post-industrial society : a venture in social forecasting, Basic Books, New York

[5] Daft R.L., Lengel R. H., 1984, Information richness : a new approach to managerial behavior and organizational design, in B. Staw, L.L. Cummings ed., Research in organizational behavior, vol. 6, JAI Press, Greenwich, CT

[6] Galbraith, 1968, Le nouvel Etat industriel : essai sur le système économique américain,Gallimard, Paris

[7] Drucker P., 1968, The age of discontinuity : guidelines to our changing society, Harper \& Row, New York

[8] Drucker P., 1988, The coming of the new organization, Harvard Business Review, jan-feb 1988

[9] Drucker P., 1993, L'après capitalisme

[10] Hatchuel A., 1994, Apprentissages collectifs et activités de conception, Revue Française de Gestion, $\mathrm{n}^{\circ} 99$

[11] Hatchuel A., Weil B., 1992, L'expert et le système, Economica, Paris

[12] Koenig G., 1994, L'apprentissage organisationnel : repérage des lieux, Revue Française de Gestion, n97, janvier-février 1994

[13] Leonard-Barton D., 1995, Wellspring of knowledge, Harvard Business School Press, Boston, Massachusetts

[14] Simon H.A., 1955, A behavioral model of rational choice, Quaterly Journal of Economics, 69: 99-118

[15] Skyrme D., 1994, The knowledge asset, Management Insight, n²11, David Skyrme Associates

[16] Stuart A., 1996, Knowledge Management, CIO Magazine

[17] Toffler A., 1990, Powershift : knowledge, wealth and violence at the edge of 21st century, Bantam Books, New York 